Balajti István*

\title{
Új kihívások a hazai légtérellenőrzésben
}

\section{Rendszerintegrálási alapok, passzív rádiólokáció}

\section{BEVEZETÉS - TÖRTÉNELMI ELŐZMÉNYEK}

Ismert tény, hogy hazánk a második világháború alatt képes volt a kor múszaki színvonalát (néhány paraméter tekintetében) meghaladó radarokat kifejleszteni és rendszeresíteni. Ez csak azért volt lehetséges, mert a magyar politikai-katonai vezetés felismerte a magyar rádióelektronikai iparban, a műszaki tudományok területén jelen lévő lehetőségeket, és elkötelezett szakembereket talált a feladat megoldására.[1]

A világháború súlyos károkat okozott a hazai rádiólokátor-fejlesztések területén is. Az összes katonai lokátor megsemmisült. A gyártóberendezéseket a szovjetek háborús jóvátétel címén lefoglalták és elszállították. Mindezek ellenére, az amerikai SCR-386-os radar alapján a fejlesztések újraindultak. A magyar fejlesztők az előző lokátor-fejlesztések tudásanyagát és tapasztalatait felhasználva, valamint a hazai lehetőségekre támaszkodva jelentősen továbbfejlesztették az eredetit és eltértek a szovjet másolattól is. Az új tűzvezető lokátornak a Légvédelmi Rádió Bemérő 1 (a továbbiakban LRB T-1-es) nevet adták. (1. ábra) Egy összehasonlító lövészeten, amelyen a szovjet változat tömege duplája volt a magyar lokátornak, a magyar LRB T-1-es kétszer nagyobb távolságban volt képes folyamatosan követni a céltárgyakat. Ennek ellenére - politikai nyomásra -, szovjet licenc alapján a SZON4-es és -9-es lokátorok gyártása folyt egészen 1956-ig. A hazai rádiólokátor-fejlesztések a rendszerváltást megelőző ideig megszűntek.[2] Az újrakezdéshez e cikk szerzője is hozzájárult, és talán ezzel a tanulmánnyal is növelhetővé válik a légtér szuverenitásáért felelős rádiólokátorrendszerek hatékonysága a hadrafoghatóság és költséghatékonyság területein.
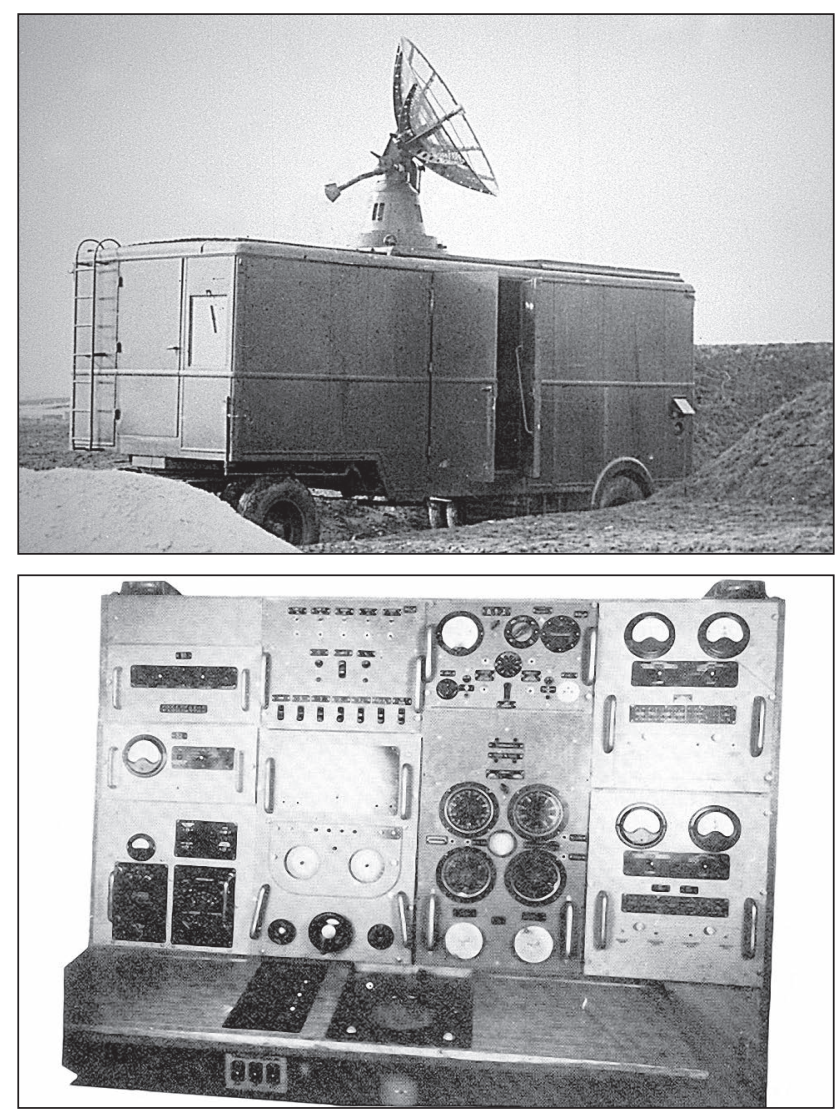

1. ábra. Az LRB rádiólokátor és vezérlőpultja [1]
ÖSSZEFOGLALÁS: A XXI. század korszerü légtérellenőrző rendszerei passzív rádiólokációval kiegészülve üzemelnek, amelyek müszaki sajátosságai és az elvárható performancia-jellemzők megváltoztatják, illetve kiterjesztik a hagyományos radarrendszerek lehetőségeit. A haderőfejlesztési program, amely Zrínyi 2026 néven ismert, lehetőséget teremt a légtérellenőrzés és a légvédelem korszerüsítésére. A fő kihívás az, hogy ezt a lehetőséget hogyan lehet a kor müszaki színvonalán, időt állóan és költséghatékonyan végrehajtani. A cikk összefoglalja a légtérellenőrzéssel kapcsolatos új kihívásokat, a napjainkban korszerünek tartott radarok legfontosabb harcászati-műszak követelményeit, rámutat a beszerzés és a rendszerben tartás sajátosságainak fontosabb elemeire, a hazai lehetőségek kiaknázásának előnyeire és kihívásaira. A szerzőnek a Haditechnika következő számában megjelenő cikke a hatékony rendszerintegrálás elvárásait vizsgálja a légtérellenőrzés alsó szintjein. Elemzi és bemutatja a hatékony passzív radarrendszer müszaki jellemzőit.

KULCSSZAVAK: rádiólokátor, passzív radar, RF hálózat központú radarrendszer, aktív zavarvédelem - ECCM
ABSTRACT: The modern air surveillance systems of the XXI century are complemented by passive radars and its technical characteristics. The expected performance will change and extend the possibilities of traditional radar systems. The Military Force Development Programme, which is known as Zrínyi 2026, provides an opportunity to modernize air surveillance, control and air defense systems. The main challenge is to implement this opportunity timely and cost-effectively to the technical standard. The first part of the article summarizes the new challenges of air surveillance and control, as well as the most important military operational-technical (Statement of Work) requirements of the radars which is considered to be relevant nowadays. It also highlights the main elements of procurement and maintenance, the benefits and challenges of exploiting domestic opportunities. The sequel examines the expectations of an effective system integration at the lower level of air surveillance and control. It analyzes and demonstrates the technical characteristics of an efficient passive radar system.

KEY WORDS: radar, passive radar, RF network centric radar systems, Electronic Counter-Countermeasures - ECCM

\footnotetext{
* Vezető mérnök, Hírközlési, Légi és Rakétavédelmi Program Mérnöki Támogató Osztály; NATO Beszerzési Ügynökség ORCID: 0000-0003-3566-2904
} 
A légtérszuverenitás-fejlesztésekkel kapcsolatos kihívások felértékelik az új típusú, valós időben megbízható információt szolgáltató új módszerek ismeretét. [3] Ezt a célt is szolgálja az IRS 2018 Nemzetközi Radar Szimpózium (Bonn, Németország, 2018. június 20-22.), és a Katonai Radar 2018 (London, Nagy-Britannia, 2018. augusztus 28-30.) rendezvényeken elhangzott előadások szelektív értékelése. [4, 5] A lehetőségek alkalmazhatóságának harcászati-műszaki és gazdasági vonzatainak figyelembevétele a projektek sikeres menedzselése szempontjából elengedhetetlen. PI. a platform alapú radarrendszerek, RF (rádiófrekvenciás) központú hálózat rendszerekké alakulnak, amelyben a passzív radarok alapvető rendszerelemek.

\section{Passziv RADAROKAT INTEGRÁLó LÉGTÉRELLENŐRZŐ RENDSZER}

A kutatott téma szempontjából kiemelt jelentősége van annak a ténynek, hogy gyakorlatban kipróbált és bevált módszereket és eszközöket reklámoznak a fejlesztő, gyártó és forgalmazó cégek, betekintést engedve számos olyan fejlesztési irányba, amelyek néhány éve még csak a közeljövő kihívásai voltak, de napjainkra már sürgető és központi elvárássá váltak. PI. polgári drónok detektálása, követése és azonosítása különböző típusú aktív zavarviszonyok között. A hatékony rendszerintegrálás elvárásainak megfogalmazásához ismernünk és osztályoznunk kell lehetőségeinket, amelyek a radarmérések szabadságfokának kiterjesztésére kell, hogy irányuljanak.

A gyakorlatban bizonyított eredmények és számítások segítségével jól szemléltethető az egyesített passzív és a hagyományos rádiólokátorok/radarcsoportok performanciája. A szakszerű vizsgálathoz a radaregyenlet egy olyan formáját alkalmazom, amely nem a maximális hatótávolság elérésének lehetőségeit vizsgálja, mint a múltban oly gyakran, hanem a céltárgyak detektálhatóságának körülményeire és lehetőségeire koncentrál. A módszer előnye az általános alkalmazhatóság, az egyszerű feladatorientált megközelítés és áttekinthetőség, párosulva a megvalósíthatóság fizikai korlátainak, pl. a céltárgy-jellemzők, az adási és vételi antenna iránykarakterisztikák átfedési elvárásai, vagy a napjainkban még a nagy radargyártó cégek belső információiként kezelt korrelációs együttható jelentőségének kimutatásával.

$$
D_{0}=\frac{S_{R}(t)}{N_{R}}=\frac{P_{\text {át }} t_{f} G_{T r} F_{T r}^{2}}{(4 \pi) L_{T r}}+\frac{\sigma(\theta) F_{p}^{2}}{(4 \pi)}+\frac{\lambda_{0}^{2} G_{R} F_{R}^{2}}{(4 \pi) k_{B} T_{S} B_{n} L_{R} R^{4}}
$$

$\mathrm{Az}$ interneten részletesen bemutatott radaregyenletnek ebben a formájában az egyenlet bal oldalán a céltárgy detektálási tényező, (maximalizált jel-zaj + zavar viszony Signal Noise Interference Ratio [SNIR]) áll, míg a jobb oldal három nagy csoportot foglal magába. Ezek az adórendszerhez, a céltárgyhoz és a vevőrendszerhez kapcsolható tényezők. A radaregyenlet fő paraméterei a radar üzemeltetési környezete által behatárolt, amelyeket az adatgyüjtés módja, az adatfeldolgozás minősége és a települési architektúra jellemez. Több radar széles spektrumtartományban és frekvenciasávban VHF, UHF, L, S és C, vett jeleinek párhuzamos feldolgozása hatékonyan a MIMO (MultipleInput and Multiple-Output - több csatornás be- és kimenő) jelfeldolgozás elvárásaival oldható meg.

Az adatgyűjtés módja szerint megkülönböztetünk: a céltárgy saját elektromágneses kisugárzását kihasználó (pl. Secondary surveillance radar - a továbbiakban SSR) külső adó által megvilágított primer (Primary surveillance radar a továbbiakban PSR); és újabban a céltárgy környezetének változását detektáló, érzékelő radarrendszereket.
A céltárgy saját kisugárzott elektromágneses jeleit mérő rendszerek kiemelt jelentőséggel rendelkeznek, mivel a hullámterjedés vesztesége „csak” négyzetes a rádiólokációban megszokott (két utas) veszteségekhez képest. Ezen az elven működnek a cseh ERA cég által forgalmazott passzív radarok, amelyek mérik és elemzik a repülőeszközök fedélzeti radar, saját-idegen felismerőberendezésének (SSR/IFF - Identification Friend or Foe) jeleit és a kommunikációs adójeleket. Ezáltal a repülőeszköz fedélzeti elektronikai berendezéseinek műszaki jellemzői kiegészítő információt szolgáltatnak a céltárgy típusára vonatkozóan. Ezt használja ki a régi/új passzív rádiólokáció (PR), amely a vételi pontok környezetében az elektromágneses spektrumtartományban mérhető rádióhullámok paramétereit méri a céltárgyak detektálására, útvonalba fogására és azonosítására. Magyar nyelven jó összefoglaló cikk található a már működő rendszerekről. [12]

A második osztályozási szempont az adatfúzió minősége szerinti megkülönböztetés, amely lehet térben koherens, térben rövid ideig koherens (CPI - Coherent Pulse Interval) és nem koherens jelfeldolgozás. A koherens jelfeldolgozás maximalizált jelfeldolgozási nyereséget ígér egy adott korrelációs időn belül. A szerző szerint az ilyen, nagyon nagy jelátviteli teljesítményt igénylő valós idejü számítógépes rendszereket nevezhetjük „RF hálózatközpontú" radarrendszereknek, szemben a napjainkban használt plot/útvonal jelentéseket integráló, kis adatátviteli kapacitásokat igénylő számítógép hálózatokkal.

A harmadik osztály a települési architektúra jelentőségét ismeri el. A kis bázisvonallal rendelkező radarrendszerek települhetnek azonos helyen, vagy egymáshoz viszonylag közel elhelyezve Gaussi monostatikus konfigurációval. Az ilyen rendszer előnye, hogy magas az elérhető korrelációs tényező, megduplázható az antennanyereség, jelentősen növelhető a mérési pontosság és kiemelkedően jó elektronikai védelem (Electronic Counter CounterMeasures ECCM vagy Electronic Protective Measures - EPM) alakítható ki. Nagy bázisvonallal telepítik a multistatikus rendszereket, hogy tovább növeljék a mérések szabadságfokát, de ennek ára a rendszerkorreláció értékének csökkenése. Ez jelentős mértékben abból fakad, hogy a légtérellenőrzési tereket, egymást többszörösen átfedő vevő- és adóantenna iránykarakterisztikák kialakítása és a közös jel

2. ábra. A légtérellenőrzési terek koherens jelintegrálásának elve

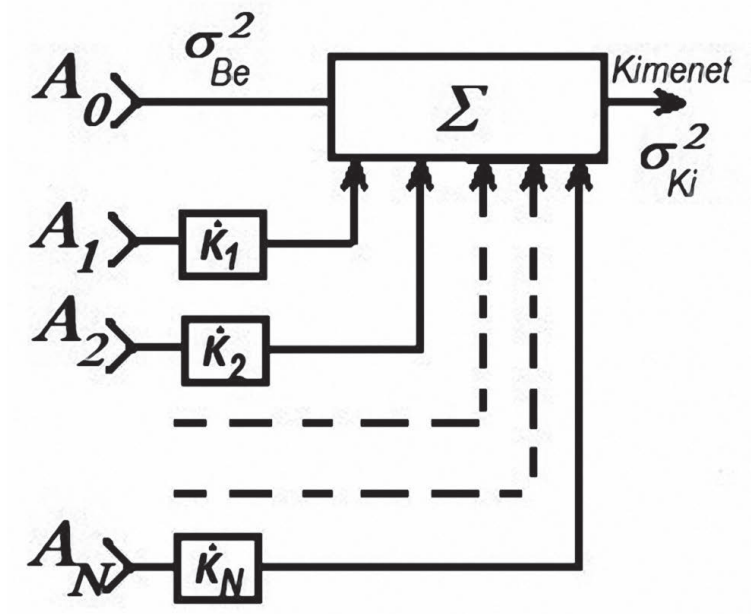


előállítás/feldolgozás komplexitása a távolságok növekedésével gyorsan nő. Ez a hátrány jelentősen csökkenthető a passzív rádiólokációs rendszerek légtérellenőrzésbe való integrálásával. A 2. ábra az RF hálózatközpontú radarrendszer antennáin vett jelek öszszegzési elvét szemlélteti.

Az RF hálózatközpontú rendszer kimenő teljesítménye $\sigma^{2}{ }_{k i}$, a rendszert alkotó $N$ számú rádiólokátor-antenna iránykarakterisztikát integráló rendszer $M$ számú egymást átfedő iránykarakterisztika által vett jelek teljesítményének összege $\sigma^{2}$. Felírható:

$$
\dot{F}_{\Sigma}\left(\theta_{j}\right)=\dot{F}_{0}\left(\theta_{j}\right)+\sum_{i=1}^{N} \dot{K}_{i} \dot{F}_{i}\left(\theta_{j}\right)
$$

Ahol: $\dot{F}_{0}\left(\theta_{j}\right)-A$ referens/bázis radarantenna performanciája, komplex függvény;

$\dot{F}_{i}\left(\theta_{j}\right)-A z$,i" radarantenna performanciája a ,j" mérés irányokban, $j=1 . . . M$, komplex függvény;

$\dot{K}_{i}-A z$,i" radar átviteli függvény komplex korrelációs tényező, a referens/bázis radarantennához viszonyítva.

Látható, hogy a referens/bázis radarantenna performanciája, települési helye és adatfúzió módja alapvetően meghatározzák az egész radarrendszer hatékonyságát. A mérési eredmények pontossága, az elérhető SNIR, végső soron a jelfeldolgozás algoritmusai és a rendszerkalibrálás korrelációs együtthatóját meghatározó lehetőségek függvénye. Ezért erre a feladatra célszerű a legkorszerübb radarok közül választani, amelyek pl. az AN/TPY-X, Smart-L, GM403-as vagy a Giraffe 8A.
A 3. ábra egy elképzelést ábrázol a XXI. század passzív és aktív radarokat integráló „RF hálózatközpontú” légtérellenőrző rendszeréről. A nagyteljesítményű TV-adó (Alkalmi adó 1) folyamatosan minden irányban sugároz, míg a $P R$ mérőpontok (Vételi pont 1 és Vételi pont 2) a veszélyeztetett irányokból folyamatosan veszik a visszavert jeleket. A vételi ponton ismerni kell az adójel paramétereit (teljesítmény, adójel moduláció, sávszélesség), amelyek meghatározzák a távolságfelbontást, a távolságmérés bizonytalanságát és az adóantenna által lefedett terület hullámterjedés viszonyait is. A passzív radar-referenciajel előállító központ, (3. ábrán PR RSP C - Passive Radar Reference Signal Processing Centre) egyszerübb működés esetén csak a műsorszóró adók jelére, többcsatornás rendszer esetén minden további alkalmi adókra, így a légtérellenőrző radarokra vonatkozóan is kidolgozza a „ref. jel” csatornán érkező szinkronizáló és a koherens jelfeldolgozáshoz szükséges helyi oszcillátor-jeleket. Mobil rendszerek esetén gyakran minden PR RSP C-hez tartozik egy mérőpont.

A rendszer előnye, hogy úgynevezett „zöld” rádiólokációs megoldás, amely integrálja a már üzemelő TV/rádió műsorszóró adókat (alkalmi adó 1), az újonnan beszerzett vagy feljavított VHF, L, S és/vagy C hullámsávban üzemelő légtérellenőrző radarokat (alkalmi adó 2), a GPS rendszer műholdjait (alkalmi adó 3), a korszerű referens/bázis mobil radart (alkalmai adó 4), csillagközi nagyteljesítményű jelforrásokat, mint a Nap, a pulzárok (alkalmi adó $\mathrm{N}$ ) vagy nagyteljesítményű zavaró adókat (drónokra vagy a világürbe telepítve). A rendszer-struktúrának és az alkalmazott múszaki megoldásoknak figyelembe kell venniük azt a tényt, hogy a referenciajel gyakran közvetlen jelként jelen van a

\section{3. ábra. Kiterjesztett alkalmazási területekkel rendelkező RF hálózatközpontú radarrendszer}

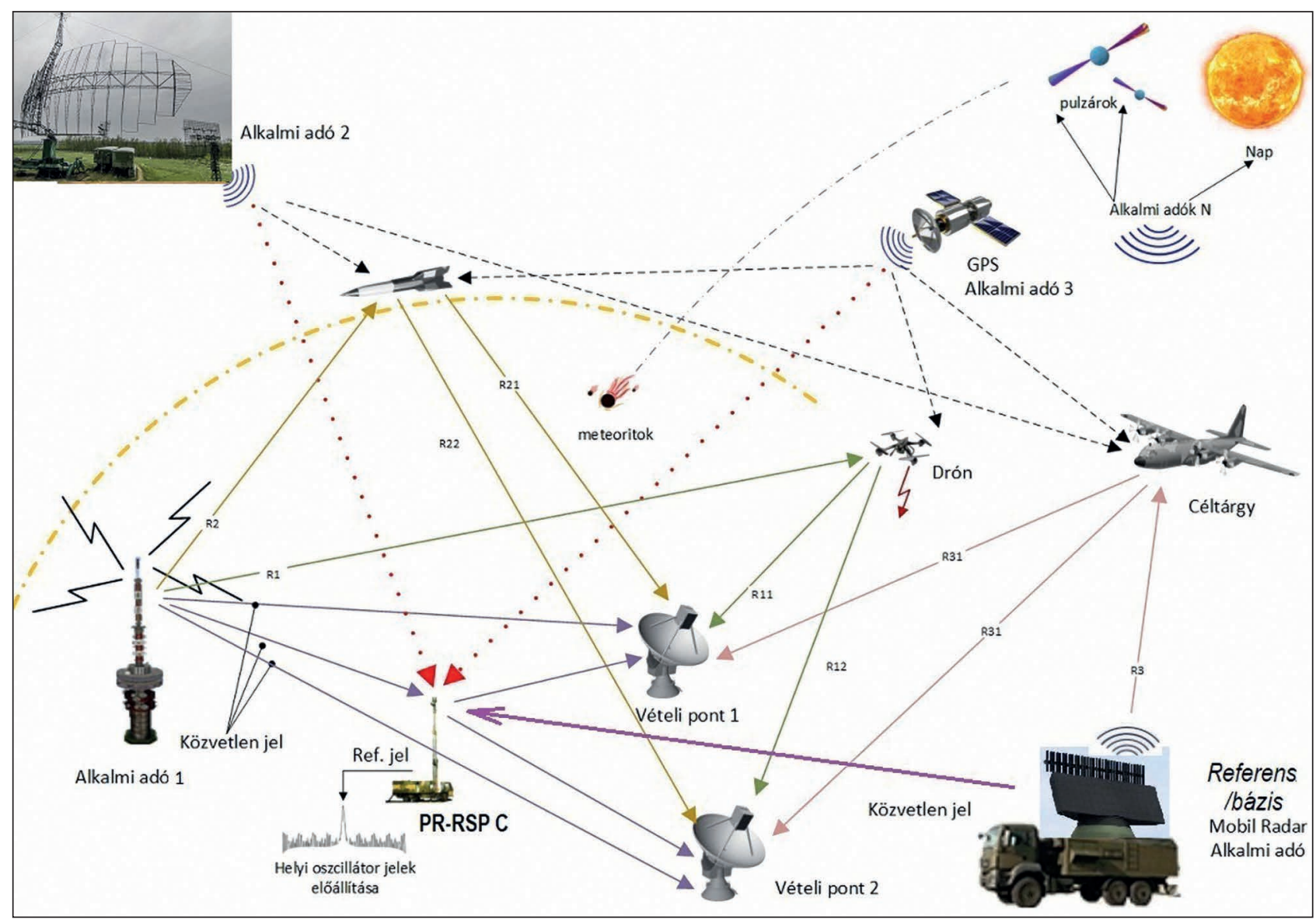


1. táblázat. A passzív radarok által használt leggyakoribb három frekvenciatartomány jellemzői

\begin{tabular}{|l|c|c|c|c|c|}
\hline & $\begin{array}{c}\text { Frekvencia- } \\
\text { tartomány }\end{array}$ & $\begin{array}{c}\text { Alkalmazható } \\
\text { adórendszerek } \\
\text { max. száma }\end{array}$ & Sávszélesség & Polarizáció & $\begin{array}{c}\text { Maximális } \\
\text { hatótávolság }\end{array}$ \\
\hline $\begin{array}{l}\text { FM frekvenciatartomány: } \\
\text { Analóg FM }\end{array}$ & $87-107 \mathrm{MHz}$ & Párhuzamosan 16 & $150 \mathrm{MHz}$ & Függőleges & $250 \mathrm{~km}$ \\
\hline $\begin{array}{l}\text { VHF frekvenciatartomány: } \\
\text { DAB }\end{array}$ & $178-240 \mathrm{MHz}$ & $4 \mathrm{TDM}$ & $1,8 \mathrm{MHz}$ & $\begin{array}{c}\text { Függöleges } \\
\text { vagy } \\
\text { vízszintes }\end{array}$ & $100 \mathrm{~km}$ \\
\hline $\begin{array}{l}\text { UHF frekvenciatartomány: } \\
\text { DVBT }\end{array}$ & $470-840 \mathrm{MHz}$ & TDM & $7,8 \mathrm{MHz}$ & $\begin{array}{c}\text { Függőleges és } \\
\text { vízszintes }\end{array}$ & $\begin{array}{c}100 \mathrm{~km} \\
(250 \mathrm{~km})\end{array}$ \\
\hline
\end{tabular}

vételi pontok antennáinak oldalnyaláb szintjein, rontva ezzel a céltárgyról detektálható jel-zaj + interferencia viszonyt és a korrelációs tényezőt. Ennek hatása jelentősen csökkenthető a korszerű ECCM megoldásokkal.

A hatékonyság növelése érdekében a vevőrendszerek általában sokcsatornás fázisvezérelt antennák csomópontjaihoz kapcsolódnak. A legfontosabb irányokban a vételi pontok közvetlen RF kapcsolatban lehetnek egymással a közös jelfeldolgozó központon (PR RSP C) keresztül. Erre a párhuzamos mérési eredmények folyamatos feldolgozása érdekében van szükség. Rendszertechnikai szempontok figyelembevételével a mobil radar adóberendezés, mint „referens/bázis” radar, a passzív rádiólokációs rendszer kívánalmainak megfelelően, része a „rendelkezésre álló/alkalmi” adórendszereknek. Ekkor az adójel paraméterei (északjel, indítás, letapogatási nyaláb oldal- és eleváció pozíció, vivőfrekvencia, adójel belső modulációja) is átadódnak a vételi pontokra. A radarantennák, mint nagy antennanyereséggel és irányszelektivitással rendelkező térbeli szűrők jelentősen kiterjesztik a passzív rendszer lehetőségeit (lásd 1. táblázat). Ezáltal optimalizálható a kis visszaverő felületû, lassú, de nagy manőverező képességgel rendelkező drónok detektálása, követése és azonosítása.

Katonai szempontból jelentős előny a rendszer rejtett üzemeltetéséből és rejtett továbbfejlesztéséből származó lehetőségek kihasználása. Ez utóbbi szempontok az élettartam logisztikai támogatásának hatékony megszervezésével megkívánják a hazai tudományos elvárások és lehetőségek kihasználását. Néhány országban erre vonatkozóan találunk példákat.

A passzív és aktív rádiólokációban kiemelt jelentősége van a mérési pontosságot, a felbontóképességet és a rendszer-kalibrációt meghatározó adójel struktúráknak. Az egymásnak ellentmondó elvárások teljesítése hibrid kódsorozatok alkalmazását várja el. Ennek a felismerésnek a gyakorlatban alkalmazható megoldására mutat példát Max lan Schöpe és társai cikke. [6]

Napjainkban egyre többször alkalmazott eljárás a GPSműhold, mint adójel-forrás felhasználása meteoritok és az alacsonypályás mủholdak detektálására és követésére. [7]

A mérési eredmények szempontjából kiemelkedő jelentősége van annak a ténynek, hogy milyen módszerrel, mérési szabadságfokkal, (pontosság, gyorsaság) határozható meg a céltárgy helyzete és az általa keltett frekvenciaváltozás. Dr. Mathini Sellathurai (Heriot-Watt University, Edinburgh) Bessel függvényeket használ a Fourier-transzformáció értékeinek kiszámítására. A radarok által mérhető mikro doppler jelenségek vizsgálatára mesterséges intelligenciát alkalmaznak a Thales kutatómérnökei. [8]

A lehetőségek közül figyelmet érdemel a passzív rendszerek feladatorientált érzékenysége. PI. a pulzárok hozzánk elérő energiaszintje olyan kicsi $-230 \mathrm{dBm} /\left(\mathrm{m}^{-2} . \mathrm{Hz}\right)$, hogy szinte fel sem merül alkalmazhatóságuk repülő objektumok detektálására. Radarrendszer kalibrációra, navigációs célokra eddig is felhasználta néhány nagy radargyártó. Napjainkban a feladat kiegészül, mivel a pulzárok rendkívül stabil energia fluktuációja 5-30 percnyi jelintegrálással lehetőséget ad pl. aszteroidák detektálására, alakjuk és mozgásjellemzőik meghatározására. [9]

\section{HADSZÍNTÉRI TAPASZTALATOKKAL RENDELKEZŐ RENDSZEREK BEMUTATÁSA}

Az IRS-2018 konferencia megnyitó előadása $A$ kiemelten jó performanciával rendelkező radarok jövőbeli müszaki kihívásai a 3. ábrán bemutatott elképzeléshez hasonló.[10] A felvázolt koncepció szerint a többfeladatú RF rendszereknek: a radaroknak, az elektronikai támogató rendszereknek (Electronic Support Measures - ESM), az elektronikai ellentevékenység (Electronic Counter Measures - ECM) és a kommunikáció/adatkapcsolatoknak egy közös hálózatban kell müködniük, amely szélessávú, aktív és elektromos nyalábmozgatással rendelkező antennarendszer (rendszerek) köré települnek. Lásd a 4. ábrán a sárga vonalakkal jelzett kapcsolatokat, és a 2. táblázatot. Miért van erre szükség?

Az új típusú fenyegetettségek jelentősen csökkentik a hagyományos rádiólokátorokban elérhető SNIR-t, egymással és a vezetési rendszerekkel elsősorban plot és útvonal alapú információ tartalommal rendelkező üzenetekkel kommunikálnak. Az ilyen típusú hagyományos rendszerek szűk frekvenciasávokat és kis adatátviteli sebességeket igényelnek, így aránylag egyszerű módszerekkel zavarhatóak. Például a céltárgyról rendelkezésre álló jelentések számának és megbízhatóságának csökkenésével.

Két radar-konferencia tapasztalata megerősíti, hogy napjaink korszerü radarrendszerei, valamint az ESM/ELINT, ECM és COMM kommunikációs rendszerek már közös, folyamatosan fejleszthető „tudás alapú” vezérlőrendszerrel rendelkeznek, amelyek közösen használhatnak széles sávú RF rendszerelemeket, és automatikusan adaptálhatók az elvárt feladatokhoz, a környezeti változásokhoz. [5] A 2. táblázat ismerteti a feladatokat és meghatározza azok végrehajtását. A radar szélessávú és/vagy több hullámsávban, pl. VHF, L S és C párhuzamosan üzemelő RF rendszerekkel párhuzamos jel- és adatfeldolgozást valósít meg a közös hálózati erőforrásokkal. Az ESM/ELINT jelzi és megjelöli a veszélyforrásokat, amelyekre a központ aktív zavarvédelem üzemmódban kognitív alapjel előállítással támogatott céldetektálásra, útvonalkövetésre és azonosításra optimalizált üzemmódokat dolgoz ki. A hálózatalapú szenzorvezérlés a rendelkezésre álló erőforrásokat a feladatvégrehajtás elvárásai szerint rangsorolja pl. nagysebességű/szélessávú és zavarvédett alacsony müholdpályás (Low Orbit Satelite LOS) kommunikációs csatornákat nyit meg. A célok azono- 


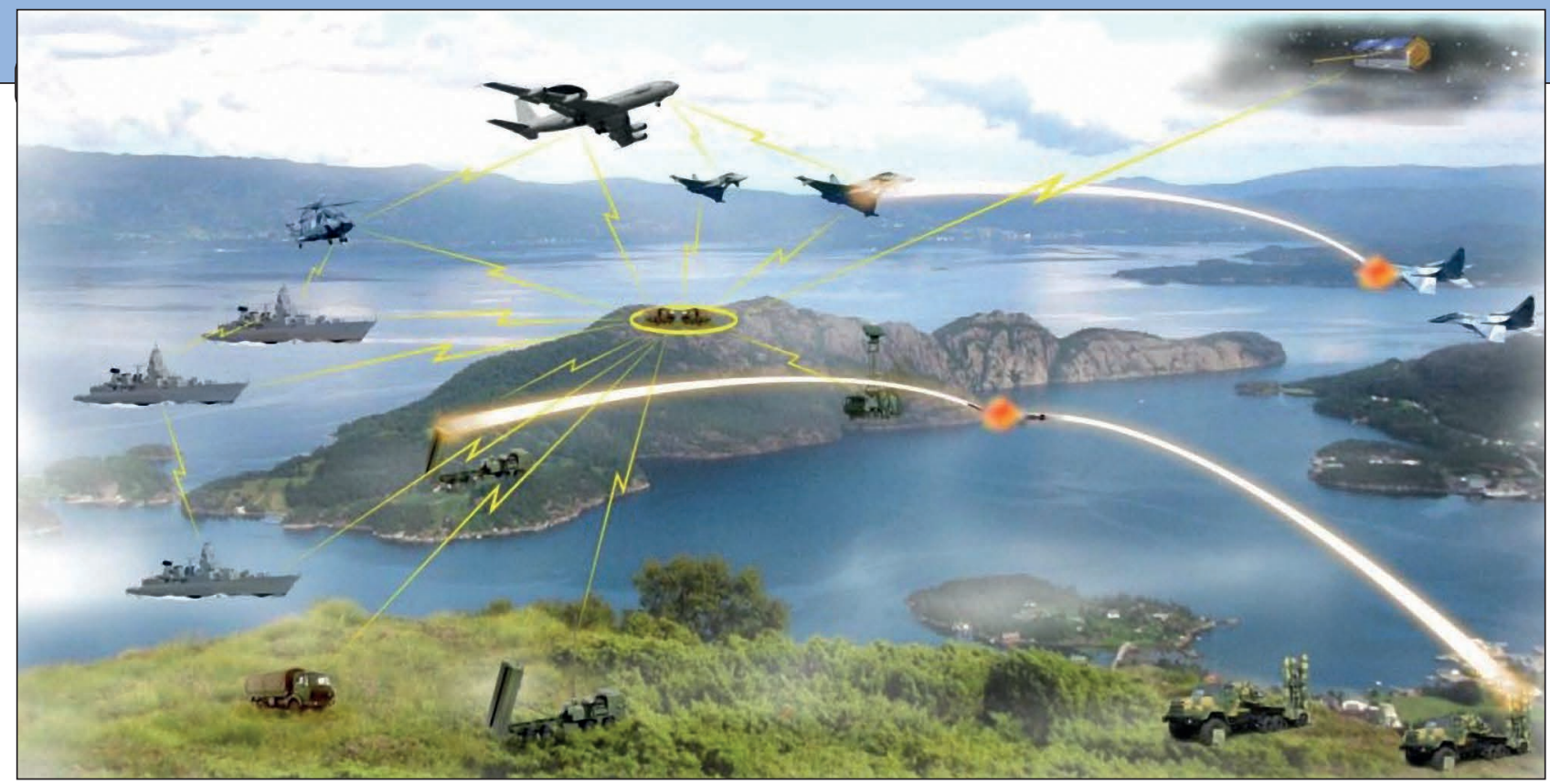

4. ábra. A platform alapú rendszerek RF hálózatközpontú rendszerekké alakulása [4]

2. táblázat. Párhuzamosan futó hálózatközpontú rendszerfeladatok

\begin{tabular}{|c|c|c|c|}
\hline Radar & ESM/ELINT & ECM & СОMМ \\
\hline $\begin{array}{l}\text { Szélessávú/Több hullámsávú } \\
\text { RF rendszerek, célkeresés: } \\
\text { - légtér, föld, tenger } \\
\text { - céltárgydetektálás }\end{array}$ & $\begin{array}{l}\text { Veszélyjelzés és } \\
\text { azonosítás }\end{array}$ & Önvédelem & Nagysebességű szélessávú LOS \\
\hline $\begin{array}{l}\text { Több hullámsávú azonosítás } \\
\text { - SAR - Spot/Strip } \\
\text { - ISAR }\end{array}$ & $\begin{array}{l}\text { Pillanatnyi irányvektor- } \\
\text { mérés és helyzet- } \\
\text { meghatározás }\end{array}$ & EMP támadás & LPI adatkapcsolati müködés \\
\hline $\begin{array}{l}\text { - Több funkciós } \\
\text { útvonalképzés/követés } \\
\text { - Jelentés megerősítés }\end{array}$ & LPI irányvektor-mérés & $\begin{array}{l}\text { Támogató zavarás } \\
\text { és megtévesztés }\end{array}$ & BLOS műhold-kommunikáció \\
\hline $\begin{array}{l}\text { Tüzkövetés: } \\
\text { • levegő-levegő-föld } \\
\text { • föld-levegő-tenger }\end{array}$ & $\begin{array}{l}\text { Azonosítás } \\
\text { és ujjlenyomat }\end{array}$ & $\begin{array}{l}\text { Követő zavarás } \\
\text { és megtévesztés }\end{array}$ & Hálózatközpontú működés \\
\hline Aktív rakéta veszélyjelzés & Passzív felderítés & $\begin{array}{l}\text { Többszörös } \\
\text { veszélyhelyzet-kezelés }\end{array}$ & Egyesített célkövető hálózat \\
\hline Javított ECCM & & & Harci azonosítási módok ID, IFF \\
\hline
\end{tabular}

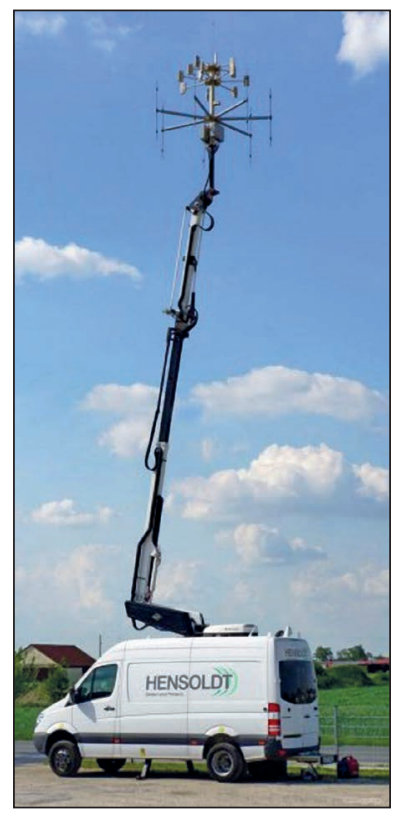

sítása több hullámsávban képalkotó/szintetikus apertúra radarokkal (SAR) és Inverse SAR-ral történik, amelyek sávokban (Strip), adott helyek (Spot) szerint radarok tapogatják le a céltárgyat és kis valószínűséggel bemérhető (Low Probability of Intercept - LPI) üzemmódban kommunikálnak egymással. A különböző helyi szenzorok jelentéseiből képzett útvonalak távoli légi helyzetkép alapján kerülnek megerősítésre, amelyet a rádió horizonton túli kommunikáció (Beyond Line of Sight - BLOS) biztosít és kapcsol a szövetséges rendszerekhez.

A tűzkövető rendszerek hatásfoka növelhető a hálózatközpontú támogatás, pl. ujjlenyomat-képzés/ képalkotás (ISAR), végső soron a célazonosítás megbízhatóbbá tételével, illetve az ECM lehetőségek szinkronizált kihasználásával.

Napjaink legelterjedtebb passzív radar működési elve PCL rendszerű (Passive Coherent Location - Passzív Koherens Helymeghatározás), amelynek egy mobil mérőpontja látható az 5. ábrán. A különböző hullámsávokban $7 \mathrm{db}$ félhullámú dipól antenna, az FM és VHF sávokban elérhető nyeresége $2 \mathrm{dBi}$, 2.5/1.3 méter átmérővel, az UHF sávban 2×16 elemmel, 8 dBi nyereséggel. Az aránylag alacsony antennanyereség ellenére a 3 mérőpontból álló rendszer valós helyzetben $200 \mathrm{~km}$-en belül folyamatosan detektálja és követi a célokat. A méréseket bemutató videókon 250 km-en belül 84 céltárgy folyamatos, fél másodperces adatfrissítéssel történő követése megoldott [11].

Az 5. ábrán látható antennarendszer előnye az oldalszög szerinti elektromos nyalábformálás, amelyet széles antenna irányélességű szögek és magas oldalnyaláb szintek jellemeznek. Ezzel szemben az 6. ábrán látható Kolchuga passzív radarantenna rendszerei irá-

5. ábra. Mobil passzív radarméröpont (FM, DAB, DVB-T) [4]

$6 \rightarrow$ HADITECHNIKA LIII. évf. - 2019/2 


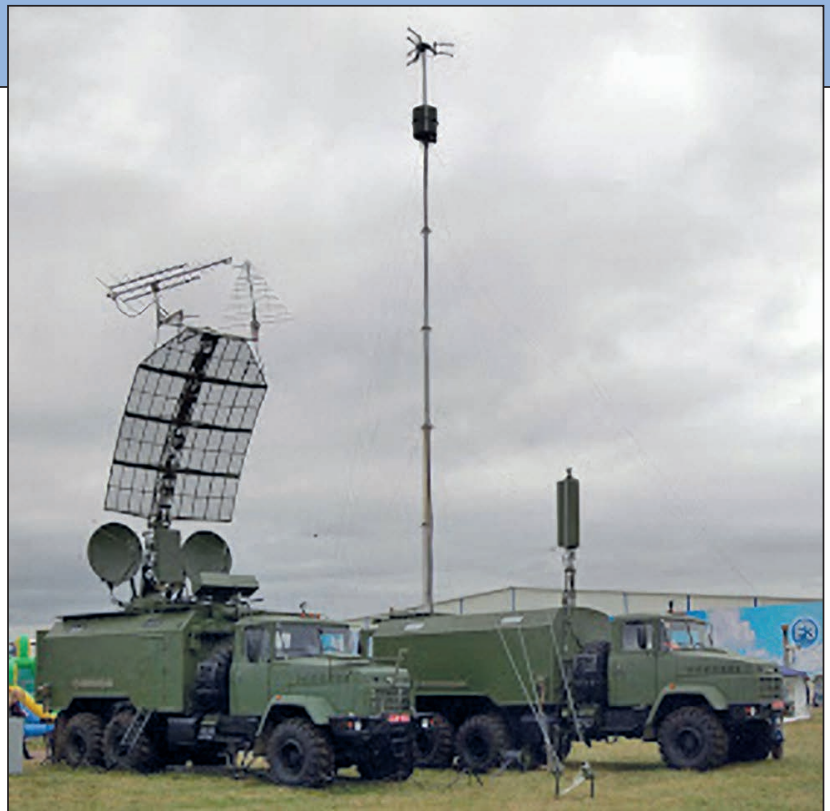

6. ábra. A Kolchuga passzív radar egyik mérőpontja $[4,12]$

nyítottságának és nyereségének köszönhetően jelentős, több százszor nagyobb SNIR-re képes, (az új típusú kihívásokkal jellemzett célok észlelésére, útvonalba fogására és azonosítására), igaz csak a vizsgált oldalszög szektorokban. Két-három mérőpont a 3 . ábrán bemutatott módon és az előzőekben ismertetett eljárásokkal dolgozik. A rendszer titka a hadszíntéri tapasztalatok beépítése a rendszer algoritmusaiba. Ukrajna és Oroszország (Kína?) egymástól függetlenül folyamatosan továbbfejleszti ezt a rendszert. [12] Oroszország napjainkban a 4-k verziót használja az S-400as, nagy hatótávolságú légvédelmi rendszereihez. (2018. év végi hír szerint Oroszország rendszerbe állítja a legújabb S-350 jelű légvédelmirakéta-rendszert és bár adatai titkosak, az aktív és passzív radar rendszerei nagyon jó performanciával kell, hogy rendelkezzenek - Szerk.)

\section{Összegzés}

Napjaink légtérellenőrző és légvédelmi rendszerei egyedi hordozóplatformra szerelt érzékelő és légvédelmi csapásmérő eszközök, amelyek aránylag szűk átviteli adatforgalmat megvalósító IT-alapú számítógéphálózat-központú adatforgalmat valósítanak meg. Ezzel szemben az „RF hálózatközpontú” rendszer valós idejű adatátviteli sávszélessége 10-100 ezerszer nagyobb, mivel az ilyen szenzor elemeket közös RF erőforrásként kezelik az ESM/ELINT, ECM, ECCM és COMM rendszerek katonai felhasználói.

Bővített alkalmazási területekkel rendelkező „RF hálózatközpontú” radarrendszer és a már üzemelő passzív rendszerek performancia jellemzőinek összehasonlítása azt bizonyítja, hogy a rendszer megvalósítható a jelenlegi számítástechnikai és RF technológia szintjén. A passzív radarrendszer performanciák kiegészítése primer radarokkal, különösen az „m”-es a „dm”-es és a „cm”-es rádiólokációra használt hullámtartományokban ígéretes, ahol a nagy nyereségű és irányítottságú radarantennák által vett jelek a térletapogatás elvárásai szerint 10-100 szorosára növelhetik a hasznos információk mennyiségét és minőségét.

A cégek ajánlatai között jelentős különbségek figyelhetők meg, az RF eszközök (antennák, szintézerek, erősítők) elvárásai és rendszer kalibrációja, a megfelelő információszűrő alkalmazásokkal támogatott döntés-előkészítés, erőforrás optimalizáló algoritmusok kidolgozottságának területein. A fejlődés rendkívül gyors, hiszen a nagyteljesítményű, kis fáziszajjal rendelkező rádiófrekvenciás antenna, adó- és vételi egységek megbízható működése elérte a
$100 \mathrm{GHz}-\mathrm{ig}$ terjedő frekvenciasávot. A megnövekedett processzor-teljesítmények, a gyors és olcsó hálózati eszközök (beleértve a wireless és lézeres eszközöket is) elterjedésével új lehetőségek jelentenek a hálózaton rendelkezésre álló nagy mennyiségű információ feldolgozására, a légtér-ellenőrzési feladatok minőségi megoldására.

Az előnyök mellett jelentkező radarrendszer üzemeltetési és fenntartási kockázatainak csökkentése, a technológia és a tudomány új eredményeinek költséghatékony rendszerintegrációja megköveteli az eszközök élettartam-ciklusra vonatkozó hazai ipari-tudományos lehetőségeinek minél szélesebb körű kihasználását.

Történelemi tapasztalatainkra támaszkodva (az LRB T-1 kapcsán egyszer már elkövetett hibák) felmerül a kérdés, hogy egy új rendszer kialakításakor sikerül-e egy költséghatékony, a helyi lehetőségeket ötvöző és a kockázatokat minimalizáló megoldást találni.

FORRÁSOK

[1] István Balajti - Ferenc Hajdú: Surprising findings from the Hungarian radar developments in the era of the second world war, Radio Science Bulletin 358. (2016, september) pp. 82-108, http://www.ursi.org/content/ RSB/RSB_358_2016_09.pdf (Letöltés ideje: 2018/08/11);

[2] Hajdú Ferenc - Sárhidai Gyula: A Magyar Királyi Honvéd Haditechnikai Intézettől a HM Technológiai Hivatalig 1920-2005, HM Technológiai Hivatal, 2005, p. 109;

[3] Balajti István: A magyar légtérellenőrzés jövőbeni műszaki kihívásai, Haditechnika, 2018/2, pp. 27-31., DOI: 10.23713/ht.52.2.07;

[4] 2018 19th International Radar Symposium (IRS 2018), Proceedings alfejezetek előadásai, 2018 június 20-22, Bonn, Németország;

[5] Military Radar Conference, London, UK, 2018; https:// militaryradar.iqpc.co.uk/ (Letöltés ideje: 2018/08/11);

[6] Max lan Schöpe et al.: Using Golay Sequences to Improve the Range Performance of Hybrid Codes for MIMO Radar. IRS 2018 - International Radar Symposium. DOI: 10.23919/IRS.2018.8448132;

[7] Observation of Falling Cosmic Objects Using GPS-Based FSR. H. Kabakchiev et al. IRS 2018 - International Radar Symposium DOI: 10.23919/ IRS.2018.8447936;

[8] Frédéric Barbaresco: Radar Micro-Doppler Signal Encoding in Siegel Unit Poly-Disk for Machine Learning in Fisher Metric Space. IRS 2018 - International Radar Symposium. DOI: 10.23919/ IRS.2018.8448021

[9] Andon Lazarov, Christo Kabakchiev, Chavdar Minchev, Ivan Garvanov: Passive Aperture Synthesis Using Pulsar's Emissions. IRS 2018 - International Radar Symposium. DOI: 10.23919/IRS.2018.8448231

[10] Ryszard Bil et al.: Future Technological Challenges for High Performance Radars. IRS 2018 - International Radar Symposium. DOI: 10.23919/IRS.2018.8447969;

[11] Steffen Lutz, Volker Winkler, Rainer Müller, Clemens Klöck: Multi Static Long Range Multi Band 3D Passive Radar - Latest Developments at Hensoldt Sensors. IRS 2018 - International Radar Symposium. DOI: 10.23919/IRS.2018.8448178;

[12] Passzív Radarok 1, 2 https://lazarbibi.blog. hu/2016/06/12/passziv_radarok https://lazarbibi.blog. hu/2016/07/12/passziv_radarok_ii_resz\#comments (Letöltés ideje: 2018/08/11). 